\title{
MOULDS AND MYCOTOXINS IN STORED MAIZE GRAINS
}

\section{Krnjaja ${ }^{1}$ J. Lević ${ }^{2}$ S. Stanković ${ }^{2}$ T. Petrović ${ }^{3}$, Z. Tomić ${ }^{1}$, V. Mandić ${ }^{1}$, Z. Bijelić ${ }^{1}$}

${ }^{1}$ Institute for Animal Husbandry, Autoput 16, P. Box 23, 11080, Belgrade-Zemun, Serbia

${ }^{2}$ Maize Research Institute "Zemun Polje", Slobodana Bajića 1, 11185, Belgrade-Zemun, Serbia

${ }^{3}$ University of Belgrade, Faculty of Agriculture, Institute of Food Technology and Biochemistry, Nemanjina 6, 11080, Belgrade-Zemun, Serbia

Corresponding author: vesnakrnjaja.izs@gmail.com

Original scientific paper

Abstract: In this study the presence of moulds and mycotoxins in samples of stored maize grains in the period from October 2011 to September 2012 was investigated. Mycological analyses of whole and broken grains showed the presence of species from the genera Alternaria, Aspergillus, Fusarium, Penicillium, Rhizopus and others. Among the Aspergillus and Fusarium genera as potentially toxigenic fungi, Aspergillus flavus was identified with the highest percentage on broken grains $(20.38 \%)$ whereas $F$. verticilioides was the predominant species in the whole maize grains (34.04\%). In addition, it was obtained that tested samples of stored maize grains were $100 \%$ positive with aflatoxin $\mathrm{B}_{1}\left(\mathrm{AFB}_{1}\right)$, zearalenone (ZON), deoxynivalenol (DON) and fumonisin $\mathrm{B}_{1}$ $\left(\mathrm{FB}_{1}\right)$ with an average concentration of $1.39 \mu \mathrm{g} \mathrm{kg}^{-1}, 71.79 \mu \mathrm{g} \mathrm{kg}^{-1}, 128.17 \mu \mathrm{g} \mathrm{kg}{ }^{-1}$, and $1610.83 \mu \mathrm{g} \mathrm{kg}^{-1}$, respectively. A significant positive correlation was found between the moisture content and the presence of Fusarium spp. on the broken grains $(\mathrm{r}=0.44)$ and between the moisture content and the concentration of DON $(\mathrm{r}$ $=0.61)$. However, a significant negative correlation was found between moisture content and $\mathrm{FB}_{1}(\mathrm{r}=-0.34)$, and between the concentration of ZON and DON mycotoxins $(\mathrm{r}=-0.58)$.

Key words: moulds, mycotoxins, storage, maize grains

\section{Introduction}

Maize (Zea mays L.) is one of the most important sources of food for human and animal nutrition and raw materials for industrial processing. In our country, maize has been grown on about 1.2 million hectares with an average yield of $5.4 \mathrm{t} \mathrm{ha}^{-1}$ and with a production of 6.5 million tons in 2011 (Statistical Yearbook of Serbia, 2012). 
The nutritional value of stored maize grains could vary significantly due to the interaction between the physical, chemical and biological factors. The contamination of maize with fungi (moulds) and mycotoxins represents a major problem for its use in human and animal nutrition. Infection of grains in the field by fungi could resulted in the production of mycotoxins during cultivation, harvesting, storage, transport and processing. The most important species of fungi and mycotoxins that could contaminate maize grains are Aspergillus flavus and aflatoxins, Fusarium verticillioides, $F$. proliferatum and fumonisins and $F$. graminearum and trichothecenes and zearalenone (Chulze, 2010). Aflatoxin causes serious problem in many foods, but it is most abundant in maize and maize products, because maize could be infected even in the field under specific environmental conditions. Contamination of maize depends on the co-existence of susceptibility of hybrids and environmental conditions favourable for proliferation of mycotoxigenic fungi (Blandino et al., 2009).

Unfortunately, there are no direct measures for prevention of infection of maize grains with ear rot fungi. However, unfavourable conditions for the development of fungi and toxinogenesis could be provided by implementation of appropriate agricultural practices as preventive measures in the field. In addition, early spring planting of maize that extends the vegetation season and selection of hybrids with higher early vigor, tolerance to biotic and abiotic stresses could be considered as an important measures for reduction of pathogenic and toxigenic fungi, resulting in an increase of maize production (Lee et al., 2002; Blandino et al., 2009).

The most common genera of fungi identified in stored maize grains are Aspergillus, Penicillium and Fusarium. The proliferation of these fungi are stimulated with higher grains moisture content, higher temperature during storage, long storage period, intensive infection by fungi before storage and by higher activity of insects and mites. Therefore, it is important to identify the species of fungi in stored maize grains with special emphasis on mycotoxigenic species, which pose a potential risk to human and animal health (Castellari et al., 2010).

Therefore, the aim of this study was to identify the most important species of fungi with special focus on Aspergillus and Fusarium species as well as to quantify the associated mycotoxins in stored maize grains, intended for feeding of domestic animals (pigs, sheep and poultry).

\section{Materials and Methods}

For mycological and mycotoxicological analysis of maize grains in the warehouse of the Institute for Animal Husbandry, Belgrade, samples were randomly taken according to the Commission Regulation (EC) No 401/2006 (European Commission, 2006) on every month during 12 months, from October 
2011 to September 2012. Moisture content of maize grains was determined using a moisture analyzer (OHAUS MB35, USA).

Twelve different samples of maize were tested by mycological methods, where in each sample 200 whole and 200 broken grains were analyzed. The grains were first rinsed by tap water, then disinfected in a $1 \%$ solution of sodium hypochlorite $(\mathrm{NaOCl}) 3-5$ minutes and distributed on the surface of water agar (WA) in Petri dishes (5 grains per Petri dishes) and incubated in a thermostat for 57 days at $25^{\circ} \mathrm{C}$. Identification of colonies of fungi that overgrowth the maize grains was done by microscopic examination of mycelium and spores, according to Burgess et al. (1994) and Watanabe (1994). The frequency of individual species was calculated per sample according to the following equation: (Number of grains in which the fungus was detected / Total number of grains) $\mathrm{x} 100$.

Detection of aflatoxin $\mathrm{B}_{1}\left(\mathrm{AFB}_{1}\right)$, zearalenone $(\mathrm{ZON})$, deoxynivalenol (DON) and fumonisin $\mathrm{B}_{1}\left(\mathrm{FB}_{1}\right)$ in a total of 12 samples was performed according to enzyme-linked immunosorbent assay (ELISA). Each sample was divided into two sub-samples, one with whole, and the other with broken grains. Individual subsample was milled in an analytical mill (IKA A11, Germany) and stored in a refrigerator at $4{ }^{\circ} \mathrm{C}$, prior to the analyses. Five grams of subsample was mixed with $1 \mathrm{~g}$ of $\mathrm{NaCl}$ and homogenized in $25 \mathrm{ml}$ of $70 \%$ methanol in a $250 \mathrm{ml}$ Erlenmeyer flask on the orbital shaker (GFL 3015, Germany) for 30 minutes. Homogenate was filtered through a Whatman filter paper 1. The filtrate was further analyzed according to the manufacturer's instructions Celery techno ${ }^{\circledR}$ ELISA kits. Absorbance was measured at a wavelength of $450 \mathrm{~nm}$ on an ELISA reader spectrophotometer (Biotek EL x 800TM, USA).

Statistical analyses. The correlation between the individual values obtained for the moisture content, the frequency of moulds and mycotoxins concentration was performed using Pearson's correlation coefficient.

\section{Results}

The moisture content of the samples of stored maize was in the range of 9.26 to $12.58 \%$ with an average moisture content of $11.02 \%$.

In the stored maize grains it was identified several fungal genera, as followed: Alternaria, Aspergillus, Fusarium, Penicillium, Rhizopus and others. By observing the average presence of the isolated fungi in the both grains (whole and broken) it was obtained that most of the genera were more frequent in the broken compared to whole grains, except Fusarium, whose representatives were more frequent in the whole grains $(38.6 \%)$ compared to the broken grains $(25.3 \%)$. Toxigenic species of the genus Aspergillus were present at levels ranging from 0 (March, April, and June 2012) to 39\% (August 2012) in the whole maize grains, with an average frequency of $14.5 \%$ for all investigated months. These species were present in the range from 0 (April 2012) to 68.5\% (July 2012) in the broken 
maize grains with an average of $23.7 \%$ for all investigated months. Fusarium species were present in the range from 3 (October 2011) to 97.5\% (June 2012) in the whole grains and 2.5 (January 2012) to 77\% (June 2012) on a broken maize grains (Table 1).

Weak positive correlation was found between moisture content and frequency of Aspergillus spp. $(\mathrm{r}=0.17)$ and Fusarium spp. $(\mathrm{r}=0.18)$ in the whole maize grains. Statistically significant correlations were found between the moisture content and Fusarium spp. $(\mathrm{r}=0.44)$ to a broken maize grains and statistically insignificant negative correlation $(\mathrm{r}=-0.09)$ between the moisture content and Aspergillus spp.

Table 1. Frequency of fungal genera in stored maize grain samples during investigated period

\begin{tabular}{|c|c|c|c|c|c|c|c|c|c|c|c|c|}
\hline \multirow{4}{*}{ Sample $^{\mathrm{a}}$} & \multicolumn{12}{|c|}{ Fungal genera } \\
\hline & \multicolumn{2}{|c|}{ Alternaria } & \multicolumn{2}{|c|}{ Aspergillus } & \multicolumn{2}{|c|}{ Fusarium } & \multicolumn{2}{|c|}{ Penicillium } & \multicolumn{2}{|c|}{ Rhizopus } & \multicolumn{2}{|c|}{ Other } \\
\hline & $\mathrm{W}$ & $\mathrm{B}$ & $\mathrm{W}$ & $\mathrm{B}$ & $\mathrm{W}$ & $\mathrm{B}$ & $\mathrm{W}$ & $\mathrm{B}$ & $\mathrm{W}$ & $\mathrm{B}$ & $\mathrm{W}$ & $\mathrm{B}$ \\
\hline & \multicolumn{12}{|c|}{ Percentage of infected grains } \\
\hline 1 & 2.5 & 15.5 & 4.5 & 12 & 3.0 & 36.5 & 4.5 & 35.0 & 47.5 & 31.5 & 14.0 & 0.0 \\
\hline 2 & 0.0 & 1.5 & 8.0 & 19 & 12.0 & 22.5 & 0.0 & 18.0 & 83.0 & 73.0 & 0.0 & 0.0 \\
\hline 3 & 4.5 & 0.0 & 11.0 & 18.5 & 52.5 & 45.0 & 2. & 9.5 & 22.0 & 5.0 & 4.0 & 0.0 \\
\hline 4 & 0.0 & 7.5 & 23.0 & 50 & 36.5 & 2.5 & 1.5 & 24.5 & 37.5 & 63.0 & 1.5 & 1.0 \\
\hline 5 & 14 & 2.5 & 14.0 & 20.5 & 20.5 & 27.5 & 14.0 & 48.5 & 45.5 & 29.5 & 1.0 & 0.0 \\
\hline 6 & 32 & 43.0 & 0.0 & 20.5 & 45.5 & 14.0 & 0.0 & 21.5 & 22.5 & 37.5 & 13.5 & 10.5 \\
\hline 7 & 0.0 & 23.5 & 0.0 & 0.0 & 35.0 & 17.0 & 39.5 & 46.0 & 11.0 & 18.5 & 1.0 & 0.0 \\
\hline 8 & 0.0 & 0.0 & 5.5 & 3.5 & 46.0 & 11.5 & 34.5 & 67.5 & 23.0 & 47.0 & 0.0 & 0.0 \\
\hline 9 & 0.0 & 0.0 & 0.0 & 5.5 & 97.5 & 77.0 & 3.0 & 20.0 & 3.5 & 20.0 & 0.0 & 5.5 \\
\hline 10 & 2.5 & 0.5 & 37.0 & 68.5 & 9.5 & 4.0 & 13.5 & 5.0 & 2.0 & 27.0 & 0.5 & 0.0 \\
\hline 11 & 0.0 & 5.0 & 39.0 & 25 & 37.0 & 29.0 & 1.5 & 6.0 & 30.0 & 5.5 & 0.5 & 12.5 \\
\hline 12 & 0.5 & 0.0 & 32.0 & 41 & 40.5 & 16.5 & 1.5 & 2.0 & 3.5 & 44.5 & 21.5 & 16.0 \\
\hline Average & 4.7 & 8.3 & 14.5 & 23.7 & 38.6 & 25.3 & 9.7 & 25.3 & 27.6 & 37.7 & 4.8 & 3.8 \\
\hline
\end{tabular}

${ }^{\mathrm{a}}$ The dates when the samples were collected: 1 - October 2011; 2 - November 2011; 3 - December 2011; 4 - January 2012; 5 - February 2012; 6 - March 2012; 7 - April 2012; 8 - May 2012; 9 - June 2012; 10 - July 2012; 11 - August 2012; 12 - September 2012;

$\mathrm{W}$ - Whole maize grains; B - Broken maize grains

Statistical high positive correlation was found between contamination of whole and broken grains with Aspergillus spp. $(\mathrm{r}=0.79)$, Penicillium spp. $(\mathrm{r}=$ $0.74)$ and Alternaria spp. $(\mathrm{r}=0.72)$ whereas it was significant with Fusarium spp. $(\mathrm{r}=0.61)$ and Rhizopus spp. $(\mathrm{r}=0.51)$. Interrelationship of identified species of fungi in the whole and broken grains was generally negatively correlated, which was not statistically significant, except in the case of Aspergillus spp. and Fusarium spp. $(\mathrm{r}=-0.52)$ and Aspergillus spp. and Penicillium spp. $(\mathrm{r}=-0.59)$ on the broken grains and Fusarium spp. and Rhizopus spp. on the whole grains (r = 0.52 ). The positive correlation that was not statistically significant, was found only between Aspergillus spp. and Rhizopus spp. $(\mathrm{r}=0.16)$, and Alternaria spp. and 
Penicillium spp. $(\mathrm{r}=0.14)$ on a broken grains as well as between Rhizopus spp. and Alternaria spp. $(\mathrm{r}=0.02)$ on the whole grains.

From the tested grains, A. flavus, A. parasiticus and A. niger were isolated as the main species of the genus Aspergillus, whereas $F$. gramineraum, $F$. proliferatum, $F$. subglutinans and $F$. verticillioides were isolated as species of the genus Fusarium. Generally, Aspergillus species were more presented on the broken grains, compared with whole grains of the stored maize (Table 2). From the Aspergillus species, A. flavus was the most presented on both the whole $(12.3 \%)$, and the broken grains (20.38\%). Of all identified species, including Fusarium spp., the most common species was $F$. verticillioides, on the whole (34.4\%) and broken maize grains $(23.9 \%)$.

Table 2. Frequency of Aspergillus spp. and Fusarium spp. in investigated stored maize grain samples

\begin{tabular}{|l|c|r|}
\hline \multirow{2}{*}{ Fungal species } & \multicolumn{2}{|c|}{ Percentage of infected grains } \\
\cline { 2 - 3 } & $\mathrm{W}$ & $\mathrm{B}$ \\
\hline Aspergillus flavus & 12.25 & 20.38 \\
\hline Aspergillus parasiticus & 0.08 & 0.33 \\
\hline Aspergillus niger & 2.17 & 2.96 \\
\hline Fusarium graminearum & 0.17 & 0.33 \\
\hline Fusarium proliferatum & 0.29 & 0.0 \\
\hline Fusarium subglutinans & 4.13 & 1.0 \\
\hline Fusarium verticillioides & 34.04 & 23.92 \\
\hline
\end{tabular}

$\mathrm{W}$ - Whole maize grains; $\mathrm{B}$ - Broken maize grains

Concerning the presence of $\mathrm{AFB}_{1}, \mathrm{ZON}, \mathrm{DON}$ and $\mathrm{FB}_{1}$, it was detected in all tested samples with an average concentrations of $1.39 \mu \mathrm{g} \mathrm{kg}^{-1}$, (range 0.33 to $2.40 \mu \mathrm{g} \mathrm{kg}^{-1}$ ), $71.79 \mu \mathrm{g} \mathrm{kg}^{-1}$ (range 15.44-188.05 $\mu \mathrm{g} \mathrm{kg}^{-1}$ ), $128.17 \mu \mathrm{g} \mathrm{kg}^{-1}$ (range 41$226 \mu \mathrm{g} \mathrm{kg}^{-1}$ ) and $1610.83 \mu \mathrm{g} \mathrm{kg}^{-1}$ (range $880-2950 \mu \mathrm{g} \mathrm{kg}^{-1}$ ), respectively (Table 3).

A significant positive correlation has only been found between moisture content and DON $(r=0.61)$, while for the other mycotoxins tested this correlation was negative for $\mathrm{AFB}_{1}(\mathrm{r}=-0.07)$, ZON $(\mathrm{r}=-0.25)$ and $\mathrm{FB} 1(\mathrm{r}=-0.34)$. The correlation between the concentrations of $\mathrm{ZON}$ and DON was significantly negative $(\mathrm{r}=-0.58)$, and between $\mathrm{AFB}_{1}$ and $\mathrm{FB}_{1}$ was statistically insignificant negative $(\mathrm{r}=-0.08)$.

Table 3. Concentration of aflatoxin $\mathrm{B}_{1}\left(\mathrm{AFB}_{1}\right)$, zearalenone (ZON), deoxynivalenol (DON) and fumonisin $B_{1}\left(F_{1}\right)$ in investigated stored maize grain samples

\begin{tabular}{|l|c|c|c|c|}
\hline Item & $\mathrm{AFB}_{1}$ & ZON & DON & $\mathrm{FB}_{1}$ \\
\hline Sample size & $12 / 12$ & $12 / 12$ & $12 / 12$ & $12 / 12$ \\
\hline Incidence $(\%)$ & 100 & 100 & 100 & 100 \\
\hline Range $\left(\mu \mathrm{g} \mathrm{kg}^{-1}\right)$ & $0.33-2.40$ & $15.44-188.05$ & $41-226$ & $880-2950$ \\
\hline Mean $^{\mathrm{b}}\left(\mu \mathrm{g} \mathrm{kg}^{-1}\right)$ & 1.39 & 71.79 & 128.17 & 1610.83 \\
\hline
\end{tabular}

${ }^{a}$ Number of positive samples/Number of total samples

${ }^{\mathrm{b}}$ Mean concentration in positive samples 


\section{Discussion}

In this study the presence of potentially toxigenic fungi of the genera Aspergillus (A. flavus) and Fusarium ( $F$. verticillioides) on the stored maize grains was performed. The obtained results are in agreement with previous investigations reported by Hell (2003), Krnjaja et al. (2007) and Amadi and Adeniyi (2009). By mycological testing of 86 samples of stored maize, originating from different farms in two locations in Kenya, it was found that the most frequently isolated species were from the genera Aspergillus (35.8\%), and Fusarium (15.5\%), followed by Penicillium (9.2\%), Rhizopus (5.3\%) and others (34.4\%) (Bii et al., 2012).

The co-occurrence of toxigenic fungi is not uncommon feature. During the study period it was found the co-occurrence of identified genera Aspergillus, Fusarium, Penicillium and Rhizopus, especially on broken maize grains. Also, Remešova et al. (2007) isolated the same genera of fungi in healthy and damaged maize, but with different frequency. In the study of Miller (1993) it was also found frequent joint occurrence of $A$. flavus and $F$. verticillioides on maize. It has already been reported that damage of maize germ has the greatest impact on the proliferation of moulds (Tuite et al., 1985).

Although in the tested samples almost all fungi were identified, their ratio was still generally negatively correlated, both in the whole, and the broken maize grains. Contrary to wheat, where statistically highly significant negative correlation between Fusarium spp. and Alternaria spp. was found (Lević et al., 2012) on maize grains this negative correlation was not statistically significant.

Aflatoxins and fumonisins, synthesized mainly by $A$. flavus and $F$. verticillioides, respectively, are among the most important mycotoxins that can cause economic losses in maize production. In this research, the co-occurence of aflatoxin $B_{1}$ with fumonisin $B_{1}(100 \%)$ was found, which is similar to the observations of Kimanya et al. (2008), Sun et al. (2011) and Krnjaja et al. (2013).

All of the samples in this study were positive on the presence of Fusarium toxins, fumonisin $\mathrm{B}_{1}$, deoxynivalenol and zearalenone which is in accordance with the results of Lazzari (1994). Because there are favourable conditions for the growth and development of these fungi and mycotoxin contamination of maize grains, in Serbia it is of outmost importance to implement the preventive measures to reduce the risk of these contaminants, especially in years when weather conditions are suitable for their development. The weather conditions before and during the maize harvest could affect the safety of grains during storage. In the period of maize silking, high ambient temperature and high humidity could favour infection of grains with Aspergillus species particularly by Aspergillus flavus and mycotoxins. Fusarium ear rot of maize caused mostly by $F$. verticillioides and $F$. proliferatum is also stimulated by warm weather, dry seasons and increased damage of ear by insects (Miller, 1995). Drought, inadequate nutrition of plants, other agents of plant diseases, insects, weeds and excessive plant populations can 
cause stress in plants and facilitate the infection of maize grains by toxigenic fungi. Sowing the right (adapted) hybrids, optimum plant nutrition, irrigation and insect control would certainly help to reduce mycotoxins contamination. Early harvesting and artificial drying reduces the occurrence of mycotoxins contributed the prevention of grain breakage and protect grain from insect pests (Bruns, 2003). Good ventilation of warehouse has also been one of the most important preventive measures for the reduction of mycotoxins production (Jakic-Dimic et al., 2011).

Contamination of maize by mycotoxins has been increasing worldwide, as a result of climate change, growing of high-yielding hybrids susceptible to infection with toxigenic fungi and accumulation of mycotoxins in crop products, especially in wheat. Some mycotoxins could be synthesized in maize before harvest but their concentration may increase after harvest during the storage period and further in the food chain. Preventive measures, such as fast drying of maize for the medium and long-term storage in hygiene maintained warehouses, without the presence of insects and microorganisms, and proper regulation of grains moisture content, could significantly reduce the mycotoxins contamination of maize grains.

\section{Conclusion}

Based on the obtained results it can be concluded that the potentially toxigenic species of fungi from the genera Aspergillus and Fusarium were significantly presented in the stored maize grains. During the storage period (October 2011 - September 2012) Aspergillus spp. was the most frequently presented in August (39\%) on the whole grains and in July (68.5\%) on the broken grains, while Fusarium spp. was most presented in June on the both, whole $(97.5 \%)$ and broken maize grains $(77 \%)$. F . verticillioides was the most common species with an average frequency of $23.92 \%$ on broken and $34.04 \%$ on the whole maize grains. In addition, A. flavus was generally less presented on the whole $(12.25 \%)$ than on the broken grains $(20.38 \%)$.

Generally, it can be concluded that despite the significant presence of toxigenic species on the maize grains, the concentration of mycotoxins $\mathrm{AFB}_{1}$, ZON, DON and $\mathrm{FB}_{1}$ has not exceed the maximum allowed concentrations prescribed by Regulation on the quality of animal feed (Article 99) (Official Gazette of the Republic of Serbia, 2010). These results indicated that the stored maize was suitable for feeding of farm animals (pigs, sheep and poultry).

\section{Acknowledgment}

This work was supported by the Ministry of Education, Science and Technological Development, Republic of Serbia within projects TR-31023, TR31053 and TR-46010. 


\title{
Plesni i mikotoksini u uskladištenom kukuruzu
}

\author{
V. Krnjaja, J. Lević, S. Stanković, T. Petrović, Z. Tomić, V. Mandić, Z. Bijelić
}

\section{Rezime}

$\mathrm{U}$ radu je ispitivano prisustvo plesni i mikotoksina u uzorcima zrna uskladištenog kukuruza u periodu od oktobra 2011. do septembra 2012. godine. Mikološkim analizama celog i slomljenog zrna kukuruza ustanovljeno je prisustvo vrsta iz rodova Alternaria, Aspergillus, Fusarium, Penicillium, Rhizopus i drugih. Od potencijalno toksigenih vrsta iz rodova Aspergillus i Fusarium, identifikovane su u najvećem procentu $A$. flavus na slomljenom $(20,38 \%)$ i $F$. verticillioides na celom zrnu kukuruza (34,04\%). Ispitivani uzorci uskladištenog kukuruza bili su $100 \%$ pozitivni sa aflatoksinom $\mathrm{B}_{1} \quad\left(\mathrm{AFB}_{1}\right)$, zearalenonom (ZON), deoksinivalenolom $(\mathrm{DON})$ i fumonizinom $\mathrm{B}_{1}\left(\mathrm{FB}_{1}\right)$ sa prosečnim koncentracijama 1,39 $\mu \mathrm{g} \mathrm{kg}^{-1}, 71,79 \mu \mathrm{g} \mathrm{kg}^{-1}, 128,17 \mu \mathrm{g} \mathrm{kg}^{-1}$ i $1610,83 \mu \mathrm{g} \mathrm{kg}{ }^{-1}$, respektivno.

Statistički značajna pozitivna korelacija ustanovljena je između sadržaja vlage i prisustva Fusarium spp. na slomljenom zrnu kukuruza $(\mathrm{r}=0,44)$, kao i između sadržaja vlage i koncentracije DON $(r=0,61)$. Statistički značajna negativna korelacija ustanovljena je između sadržaja vlage i $\mathrm{FB}_{1}(\mathrm{r}=-0,34)$, kao i između koncentracija ZON i DON mikotoksina $(\mathrm{r}=-0,58)$.

\section{References}

AMADI J.E., ADENIYI D.O. (2009): Mycotoxin production by fungi isolated from stored grains. African Journal of Biotechnology, 8, 7, 1219-1221.

BII F., WANYOIKE W., NYENDE A.B., GITURU R.W., BII C. (2012): Fumonisin contamination of maize (Zea mays) in aflatoxin "hot" zones in Eastern province of Kenya. African Journal of Health Sciences, 20, 1-2, 28-36.

BLANDINO M., REYNERI A., VANARA F. (2009): Effect of sowing time on toxigenic fungal infection and mycotoxin contamination of maize kernels. Journal of Phytopathology, 157, 7-14.

BRUNS H.A. (2003): Controlling aflatoxin and fumonisin in maize by crop management. Journal of Toxicology Toxin Reviews, 22, 2-3, 153-173.

BURGESS L.W., SUMMERELL B.A., BULLOCK S., GOTT K.P., BACKHOUSE D. (1994): Laboratory Manual for Fusarium Research. Third edition. Fusarium Research Laboratory, Department of Crop Sciences, University of Sydney and Royal Botanic Gardens, Sydney, 133 p. 
CASTELLARI C., MARCOS VALLE F., MUTTI J., CARDOSO L., BARTOSIK R. (2010): Toxigenic fungi in corn (maize) stored in hermetic plastic bags. JuliusKühn-Archiv, 425, 501-504.

CHULZE S.N. (2010): Strategies to reduce mycotoxin levels in maize during storage: a review. Food Additives and Contaminants, 27, 5, 651-657.

EUROPEAN COMMISSION (2006): Commision regulation (EC) No. 401/2006. Official Journal of the European Union, L70, 12.

HELL, K., CARDWELL, K.F., POEHLING, H.M. (2003): Relationship between management practices, fungal infection and aflatoxin for stored maize in Benin. Journal of Phytopathology, 151, 690-698.

JAKIĆ-DIMIĆ D., NEŠIĆ K., ŠEFER D. (2011): Mycotoxicoses of poultry caused by trichothecenes. Biotechnology in Animal Husbandry, 27, 3, 713-719.

KIMANYA M.E., MEULENAER B.De., TIISEKWA B., NDOMONDOSIGONDA M., DEVLIEGHERE F., VAN CAMP J., KOLSTEREN P. (2008): Cooccurrence of fumonisins with aflatoxins in home-stored maize for human consumption in rural villages of Tanzania. Food Additives and Contaminants, 25, $11,1353-1364$.

KRNJAJA V., LEVIĆ J., TOMIĆ Z., NEŠIĆ Z., STOJANOVIĆ LJ., TRENKOVSKI S. (2007): Dynamics of incidence and frequency of populations of Fusarium species on stored maize grain. Biotehnology in Animal Husbandry, 23, $1,5-6,589-600$.

KRNJAJA V.S., LEVIĆ J.T., STANKOVIĆ S.Ž., PETROVIĆ T.S., LUKIĆ M.D. (2013): Molds and mycotoxins in freshly harvested maize. Matica Srpska Proceedings for Natural Sciences, 124, 111-119.

LAZZARI F.A. (1994): Occurrence of Fusarium toxins in stored maize in southern Brazil. Proceedings of the 6th International Working Conference on Stored-Product Protection, 17-23 April 1994, Canberra, Australia, 2, 1014-1016.

LEE E.A., STAEBLER M.A., TOLLENAAR M. (2002): Genetic variation in physiological discriminators for cold tolerance - early autotrophic phase of maize development. Crop Science, 42, 1919-1929.

LEVIĆ J., STANKOVIĆ S., KRNJAJA V., TANČIĆ S., IVANOVIĆ D., BOČAROV-STANČIĆ A. (2012): Relationships of mycobita on rachides and kernels of wheat. European Journal of Plant Pathology, 134, 2, 249-256.

MILLER J.D. (1993): The toxicological significance of mixtures of fungal toxins. African Newsletter on Occupational Health and Safety, 3, 2, 32-38.

MILLER J.D. (1995): Fungi and mycotoxins in grain: implications for stored product research. Journal of Stored Products Research, 31, 1, 1-16.

REMEŠOVA J., KOLAŘíK M., PRÁŠIL K. (2007): Microfungi on the kernels of transgenic and non-transgenic maize damaged by the European corn borer. Czech Mycology, 59, 2, 205-213.

OFFICIAL GAZETTE OF THE REPUBLIC OF SERBIA (2010): Regulation on the quality of animal feed, No. 4. 
SUN G., WANG S., HU X., SU J., ZHANG Y., XIE Y., ZHANG H., TANG L., WANG J.-S. (2011): Co-contamination of aflatoxin $B_{1}$ and fumonisin $B_{1}$ in food and human dietary exposure in three areas of China. Food Additives and Contaminants, 28, 4, 461-470.

TUITE J., KOH-KNOX C., STROSHINE R., CANTONE F.A., BAUMAN L.F. (1985): Effect of physical damage to corn kernels on the development of Penicillium species and Aspergillus glaucus in storage. Postharvest Pathology and Mycotoxins, 75, 10, 1137-1140.

WATANABE T. (1994): Pictorial atlas of soil and seed fungi. In: Morphologies of Cultured Fungi and Key to Species. Lewis Publishers, Boca Raton, Boston, London, Washington D.C., $410 \mathrm{p}$.

Received 18 June 2013; accepted for publication 24 July 2013 